\section{Relationships of Taste, Smell, Sight, and Touch to Forage Selection}

\author{
WILlIAM C. KRUEGER, WILlIAM A. LAYCOCK, AND DONALD A. PRICE
}

Highlight: Chemical impairment of taste, smell, and touch and physical obstruction of sight were studied in relation to forage preferences of sheep in a tall-forb plant community. Taste was the special sense most influential in directing forage preference; the other senses appeared to supplement taste. Sheep preferred sour and sweet plants and generally rejected bitter plants, although some were palatable. Smell was of minor importance in selection. Touch and sight related to such specific plant conditions as succulence and growth form. Simultaneous impairment of all four senses did not result in completely random selection, but did increase preference for unpalatable plants and decrease preference for pala table ones.

Little is known of the effect of herbivores' special senses in selection of their diet; however, it is commonly accepted that different plants within a plant community have varying palatabilities for grazing sheep. Palatability of a plant species varies somewhat depending upon its association with different plant species, but many factors interact to produce a selective response. This selective response has been termed "preference." An excellent review of important factors involved in forage selection by ruminants has been presented by Marten (1970). The study reported here was undertaken to gain insight into the basis of forage preference.

\section{Study Area and Methods}

Field sampling was conducted during the summer of 1968 on the U.S. Sheep Experiment Station summer range in the Centennial Mountains of

Krueger was range technician and Laycock is plant ecologist, International Forest and Range Experiment Station, Forest Service, U.S. Department of Agriculture, Ogden, Utah; both stationed in Logan, Utah, at the Forestry Sciences Laboratory, maintained in cooperation with Utah State University. Presently, Krueger is assistant profes sor, Rangeland Resources Program, Oregon State University, Corvallis. Price is research leader, U.S. Sheep Experiment Station, $\mathrm{Ag}$ riculture Research Service, U.S. Dep. Agr., Dubois, Id aho.

The report is part of a dissertation submitted by the senior author in partial fulfillment of the $\mathrm{PhD}$ degree in range science at Utah State University.

The authors acknowledge Dr. R. L. Hurst, head, Department of Applied Statistics and Computer Science, Utah State University, for assistance with statistical procedures.

Manuscript received October 20, 1973. southwestern Montana. The study area was $7,800 \mathrm{ft}$ in elevation and dominated by tall forbs. Eight 1/2-acre study pastures were located on a $20 \%$ slope that had a north aspect in a sticky geranium/northwest cinquefoil (Geranium viscosissimum/Potentilla gracilis) community. Two pastures were used in each of four grazing trials.

Forage production of each pasturc was sampled immediately prior to each grazing treatment. Except in one instance, 30 plots, each $4.8 \mathrm{ft}^{2}$, were located by a stratified random method in each pasture; prior to Trial 4, only 15 plots were sampled. Major plant species were clipped at ground level and weighed, and green weight of minor species was estimated. Samples of each plant species were collected and ovendried at $50^{\circ} \mathrm{C}$ to allow conversion of green weight to dry weight.

Twenty-five esophageally fistulated sheep, that had similar breeding and experiences, were used in the study. Twenty were yearlings; the rest were 2-5 years old. Only 20 sheep were used during a sampling period. However, because of problems resulting from the fistulation, occasionally an unthrifty yearling was replaced by one of the older sheep. Sampling was begun at dawn and fistulated sheep collected samples for approximately 1 hour. Prior to sampling, sheep were fasted from dark until daybreak. During the sampling period, salt and water were removed from the pastures so that chemical analyses could be performed on the samples. Results of chemical analyses will be reported in another paper. Between trials, sheep were placed in adjacent holding pastures with vegetation similar to that of the sampled pastures. Animals were allowed to graze untreated in holding pastures for 10 days prior to sensory impairment so they would become familiar with the vegetation.

Two pastures were each grazed five successive days in four different trials. Twenty sheep representing five treatments were sampled in each trial. The first trial compared forage preferences of untreated fistulated sheep with those of sheep that had a single sense impairment (Table 1). Trials 2-4 examined forage preferences of sheep that had varying combinations of sensory impairment and compared preferences with those of untreated sheep in each trial. Consequently, all possible combinations of treatments were included in the study.

Treatments to impair the senses of smell, taste, and sight were performed at least 4 days before sampling to allow sheep time to adjust to treatments. Suppression of the senses of taste and smell (ageusia and anosmia) was induced by topical application of a $2 \%$ solution of osmic acid $\left(\mathrm{OsO}_{4}\right)$. This chemical alters nerve endings, making them insensitive to stimuli for 6 months or longer (Osol and Farrar, 1955). Control of smell and taste was tested after treatments were applied for several days and for several weeks. Untreated sheep reacted vigorously to fumes from household ammonia; anosmic sheep reacted to ammonia as they did to water. Salt consumption was measured for untreated and ageusic sheep. When salt was juxtaposed with pelleted alfalfa, ageusic sheep consumed 8.7 times as much salt as untreated sheep. When salt was physically displaced and sheep had to make a deliberate selection for salt, ageusic sheep consumed only half as much as untreated sheep. Sight was controlled (anopsia) by means of a blindfold (Fig. 1). Sheep in the initial anopsic group had blindfolds in combination with other treatments throughout subsequent trials. Blindfold treatments varied for sheep that initially had other treatments (Table 1). The sense of touch in the lips was controlled (atactilia) by topical application of $5 \%$ xylocainc ointment. This treatment was applied daily immediately prior to grazing. Xylocaine is a topical anesthetic commonly used in medical practice.

Fistula samples were placed in a 20 -mesh sieve, washed in 5\% acetic acid to remove saliva, and rinsed with water. The samples were then stored on dry ice and kept frozen until analyzed. 
Plant species present in the diet were determined by a modification of Heady and Torell's (1959) technique. Each sample was thawed, spread on a tray, and 100 points were examined through a stereoscopic microscope that had a crosshair mounted in one ocular. The plant fragment directly under the crosshair was identified from epidermal characteristics. Plant fragments that could not be identified at $15 \mathrm{X}$ were removed, mounted on a slide, and examined at $125 \mathrm{X}$ (Ward, 1970).

A relative preference index (RPI) was used to evaluate forage prefererences and to minimize confounding differences in preference that might result from varying availability of plant species (Krueger, 1972). The following formula was used to determine relative preference for each plant species in each diet. Values were based on surface area of green plants:

$$
\begin{aligned}
& \text { Relative Preference Index }=\frac{\text { fd } \times D}{\text { fr } \times R} \\
& \text { Where: } f d=\text { frequency in diet } \\
& \mathbf{D}=\text { percent diet } \\
& \mathrm{fr}=\text { frequency on rangeland } \\
& \mathbf{R}=\text { percent range composition }
\end{aligned}
$$

Frequency in diet was the percentage of samples for each treatment in which a species occurred. Percent diet was the percentage of a plant species in each diet on a surface-area basis determined from microscopic point sampling. Frequency on rangeland was the percentage of plots in which a plant species occurred for each pasture grazed during each trial. Percent range composition was determined from values for green weight converted to surface area by using a small stage photoelectric planimeter (Caldwell and Moore, 1971). Interception of transmitted light for known green weights of samples of each plant species was compared to a standard curve $\left(r^{2}=\right.$ 0.99 ) and surface area in relation to weight was determined. All green weight production figures were then converted to percent surface area for use in the preference index.

A subjective evaluation of coarseness, smell, and taste was based on human sensory perception. Coarseness was evaluated by chewing the different plants and assigning them to one of three categories ("high," "moderate," or "low" coarseness). It was difficult to assign a specific smell to each plant species, although there were many distinct odors among the various plants. Smell was classified as "strong," "moderate," or "faint." Taste was classified as "bitter,"

\begin{tabular}{|c|c|c|c|c|c|c|}
\hline \multirow[b]{2}{*}{ Trial } & \multirow[b]{2}{*}{ Date (1968) } & \multicolumn{5}{|c|}{ Treatment groups } \\
\hline & & 1 & 2 & 3 & 4 & 5 \\
\hline 1 & July $22-26$ & $\mathrm{~N}^{1}$ & $A s^{2}$ & $\mathrm{Ap}^{3}$ & $\mathrm{Ag}^{4}$ & $\mathrm{At}^{5}$ \\
\hline 2 & July 30 -Aug. 3 & $\mathrm{~N}$ & Ap, As & $\mathrm{Ap}, \mathrm{Ag}$ & $\mathrm{As}, \mathrm{Ag}$ & $\mathrm{Ap}, \mathrm{At}$ \\
\hline 3 & Aug. $7-11$ & $\mathrm{~N}$ & As, At & $\mathrm{Ap}, \mathrm{Ag}, \mathrm{As}$ & As, At, $\mathrm{Ag}$ & $\mathrm{Ag}, \mathrm{At}$ \\
\hline 4 & Aug. 17-21 & $\mathrm{N}$ & As, Ap, At & As, $\mathrm{Ap}, \mathrm{Ag}, \mathrm{At}$ & $-\quad-\quad-$ & $\mathrm{Ap}, \mathrm{At}, \mathrm{Ag}$ \\
\hline
\end{tabular}
"sweet," or "sour." The categorization of these plant attributes may or may not be equivalent to the evaluation of
Table 1. Schedule of sensory impairment and grazing trials.

${ }^{1} \mathrm{~N}=$ control.

${ }^{2}$ As $=$ anosmia, sense of smell impaired.

${ }^{3} \mathrm{Ap}=$ anopsia, sense of sight impaired.

${ }^{4} \mathrm{Ag}=$ ageusia, sense of taste impaired.

${ }^{5} \mathrm{At}=$ atactilia, sense of touch impaired.

a plant by a sheep, but it did prove useful in interpreting the grazing preference of the animals.

Statistical comparisons were made by using least-squares techniques (Draper and Smith, 1966) and planned contrasts (Ostle, 1963). Each treatment was compared to the control for the same sampling period; no statistical comparisons were made across periods or among other treatments. Differences were accepted as significant at $P<0.20$. At $P<0.20$ results of statistical testing were consistent and biologically explainable. At lower levels inconsistencies not biologically explainable began to appear in data analysis.

\section{Results}

All pastures sampled during the study were similar in amount of each plant species available to the grazing sheep. To help develop a perspective of the plant community structure, average composition on a green surface area basis for important plant species

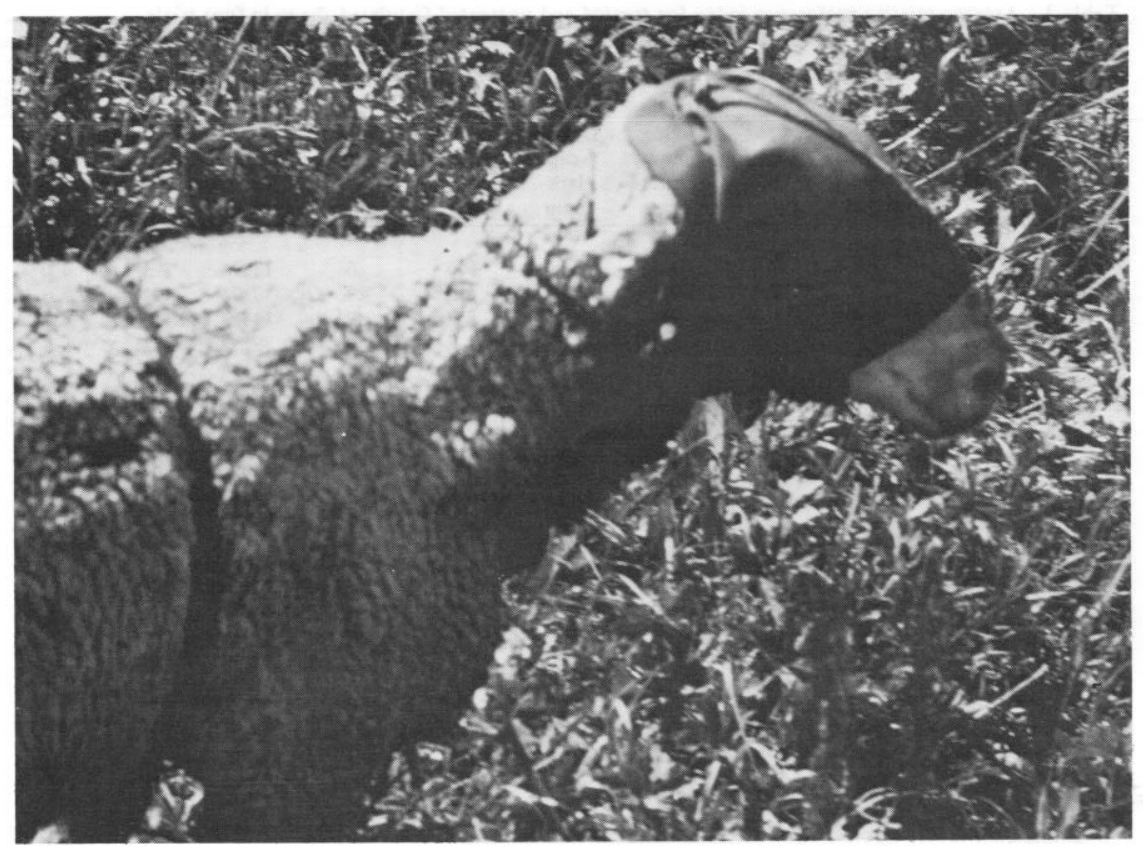

Fig. 1. Blindfold used to control vision. is presented in Table 2. Sticky geranium made up about $50 \%$ of green production on a surface area basis and had a frequency near $100 \%$. Northwest cinquefoil, second in availability, made up about $10 \%$ of the composition and had a frequency greater than $90 \%$. Mountain brome (Bromus marginatus) made up about $8 \%$ of the composition and had a frequency about $90 \%$. The most palatable plants in this community, mountain sorrel (Rumex paucifolius) and thickleaf groundsel (Senecio crassulus), made up about 1\% of the composition and were lower in frequency than the more abundant species.

Relative preference exhibited by untreated sheep varied for each time period. The effects of each treatment on preference were evaluated by comparing the control to the treatments studied only during a common trial. The average of each treatment was computed to determine the relative preference of sheep for the plant 
species studied in these pastures (Table 3). Buchanan et al. (1972) have presented preference rankings for these plants from fistulated, but otherwise untreated, animals grazing the same range. Similar palatability relationships were found in their study when these were compared to forage preferences of control sheep in this study.

Although all senses were related to preference for some plant species, tastc appcared to be the most important. Sticky geranium, classified as "bitter," was unpalatable. Compared to untreated sheep, ageusic sheep significantly preferred sticky geranium (Table 4). When all senses were impaired except taste, preference did not deviate significantly from that of control animals. When either smell, sight, or touch was controlled, preference of sheep for geranium was not significantly different from that of untreated animals. However, when taste was impaired in combination with one, two, or three other senses, the sheep showed a significant increase in their acceptance of sticky geranium.

Palatability of western yarrow (Achillea lanulosa) was also related to taste, but not as exclusively as that of sticky geranium. The only sense not eliciting rejection for yarrow was touch, an indication that western yarrow possesses many attributes that lower its palatability. In addition to having what seemed to be an un-

Table 2. Range composition (\%) of major plant species based on green surface area, and total production (lb/acre, ovendry) by trials.

\begin{tabular}{lrrrr}
\hline \hline $\begin{array}{l}\text { Measurement and } \\
\text { plant species }\end{array}$ & Trial 1 & Trial 2 & Trial 3 & Trial 4 \\
\hline Composition & & & & \\
Grasses & & & & \\
$\quad$ Alpine timothy & 3.8 & 2.4 & 1.2 & 1.2 \\
$\quad$ Mountain brome & 8.1 & 7.9 & 9.9 & 8.5 \\
$\quad$ Showy onion grass & 2.4 & .7 & 1.4 & 1.8 \\
Forbs & & & & \\
Duncecap larkspur & 3.3 & 2.9 & 1.9 & 2.8 \\
Leafybract aster & 5.5 & 5.4 & 3.6 & 4.6 \\
Mountain knotweed & 1.2 & .8 & .4 & 2.4 \\
Mountain sorrel & .8 & .4 & .2 & .2 \\
$\quad$ Northwest cinquefoil & 10.6 & 11.7 & 9.2 & 8.0 \\
Pale agoseris & 1.5 & 1.0 & .4 & .2 \\
Stickseed & 2.5 & 1.4 & 1.4 & 1.0 \\
Sticky geranium & 39.8 & 48.8 & 57.4 & 49.0 \\
Sweetanise & .6 & .9 & 1.9 & 1.0 \\
Thickleaf groundsel & .6 & 1.4 & 1.2 & 1.0 \\
$\quad$ Western valarian & 3.7 & .8 & .7 & .7 \\
$\quad$ Western yarrow & 1.5 & .9 & .6 & 1.2 \\
Total production & 1,827 & 1,748 & 1,516 & 1,570 \\
\hline
\end{tabular}

pleasant taste and smell, bitter-tasting western yarrow was also recognized by sight as being unpalatable.

Both duncecap larkspur (Delphinium occidentale) and northwest cinquefoil, both bitter-tasting plants, were more palatable when sheep had their sense of taste controlled. Because of the low availability of larkspur, valid statistical comparisons could not be made for all trials. Duncecap larkspur seemed to have an objectionable smell and taste. Touch was not related to preference for larkspur, but sight appeared to be negatively related. Blindfolded sheep showed a preference for larkspur of 5.6 compared to 0.8 for control sheep in the same trial. When sheep could see, smell, or taste, regardless of combination of treatments, preference for larkspur appeared to be lower than when these senses were controlled. Frequently, however, no statistical difference was found.

Northwest cinquefoil was another plant that significantly increased in preference when taste was controlled, but its palatability was not exclusively related to taste. Impairment of smell decreased preference for northwest

Table 3. Average relative preference index for treated and untreated fistulated sheep in four trials.

\begin{tabular}{|c|c|c|c|c|c|c|c|c|c|c|c|c|c|c|c|}
\hline \multirow[b]{3}{*}{ Trials $^{1}$} & \multicolumn{15}{|c|}{ Plant species } \\
\hline & \multicolumn{3}{|c|}{ Grasses } & \multicolumn{12}{|c|}{ Forbs } \\
\hline & $\begin{array}{l}\text { Alpine } \\
\text { timothy }\end{array}$ & $\begin{array}{c}\text { Moun- } \\
\text { tain } \\
\text { brome }\end{array}$ & $\begin{array}{l}\text { Showy } \\
\text { onion- } \\
\text { grass }\end{array}$ & $\begin{array}{c}\text { Dunce- } \\
\text { cap } \\
\text { lark- } \\
\text { spur }\end{array}$ & $\begin{array}{l}\text { Leafy- } \\
\text { bract } \\
\text { aster }\end{array}$ & $\begin{array}{c}\text { Moun- } \\
\text { tain } \\
\text { knot- } \\
\text { weed }\end{array}$ & $\begin{array}{l}\text { Moun- } \\
\text { tain } \\
\text { sorrel }\end{array}$ & $\begin{array}{l}\text { North- } \\
\text { west } \\
\text { cinque- } \\
\text { foil }\end{array}$ & $\begin{array}{l}\text { Pale } \\
\text { agos- } \\
\text { eris }\end{array}$ & $\begin{array}{c}\text { Stick- } \\
\text { seed }\end{array}$ & $\begin{array}{c}\text { Sticky } \\
\text { gera- } \\
\text { nium }\end{array}$ & $\begin{array}{c}\text { Sweet } \\
\text { anise }\end{array}$ & $\begin{array}{l}\text { Thick- } \\
\text { leaf } \\
\text { ground- } \\
\text { sel }\end{array}$ & $\begin{array}{c}\text { Western } \\
\text { valarian }\end{array}$ & $\begin{array}{l}\text { Western } \\
\text { yarrow }\end{array}$ \\
\hline \multicolumn{16}{|l|}{ No. 1} \\
\hline Control & 1.2 & 2.0 & 1.5 & .8 & 5.0 & .6 & 11.9 & 1.3 & 4.0 & 1.0 & $\mathrm{~L}^{2}$ & 36.4 & 55.7 & 1.7 & $\mathbf{L}$ \\
\hline Ap & 1.8 & 2.4 & 2.0 & 5.6 & 5.3 & .9 & 7.9 & 1.4 & 3.0 & .5 & $\mathrm{~L}$ & 7.8 & 45.8 & 1.6 & .3 \\
\hline As & 1.4 & 1.5 & 1.7 & 7.7 & 5.2 & .9 & 11.1 & 1.0 & 4.2 & 1.4 & .2 & 19.5 & 73.1 & 3.9 & .3 \\
\hline $\mathrm{Ag}$ & .2 & .8 & 1.1 & 9.5 & 4.7 & 1.0 & 2.5 & 1.7 & 5.8 & 2.3 & .2 & 24.8 & 31.5 & 1.4 & .2 \\
\hline At & 1.4 & 2.4 & 1.9 & 1.2 & 4.6 & .3 & .9 & 1.4 & 2.2 & 1.6 & .1 & 9.9 & 31.9 & 1.1 & .1 \\
\hline \multicolumn{16}{|l|}{ No. 2} \\
\hline Control & 2.2 & 2.2 & 7.6 & .5 & 6.3 & 1.7 & 37.4 & 1.1 & 3.4 & .9 & $\mathbf{L}$ & 4.6 & 14.2 & 1.3 & .2 \\
\hline Ap, As & 2.4 & 2.2 & 13.8 & $\mathrm{~L}$ & 5.6 & 2.6 & 29.6 & 1.1 & 1.4 & .8 & .1 & 8.3 & 10.0 & 3.5 & .4 \\
\hline $\mathrm{Ap}, \mathrm{Ag}$ & 2.5 & 2.2 & 9.2 & .4 & 5.4 & 1.4 & .2 & 1.5 & 1.8 & .5 & .1 & 5.5 & 6.6 & 1.0 & .8 \\
\hline $\mathrm{As}, \mathrm{Ag}$ & 1.2 & 1.4 & 7.8 & $\mathbf{L}$ & 5.0 & 1.0 & 2.2 & 2.0 & 2.8 & 2.5 & .1 & 5.9 & 5.6 & 3.7 & .5 \\
\hline $\mathrm{Ap}, \mathrm{At}$ & 2.3 & 2.1 & 9.6 & $\mathbf{L}$ & 4.5 & .3 & 11.4 & 1.1 & .9 & 1.0 & .1 & 17.8 & 2.9 & .5 & .2 \\
\hline \multicolumn{16}{|l|}{ No. 3} \\
\hline Control & 18.5 & 2.1 & 3.7 & $\mathrm{~L}$ & 9.6 & 3.7 & 69.6 & 2.0 & 25.6 & .7 & $\mathrm{~L}$ & 14.6 & 12.2 & 2.0 & .1 \\
\hline As, At & 1.2 & 1.8 & 3.0 & L & 7.8 & 8.2 & 61.4 & 1.4 & 3.2 & 4.5 & .1 & 8.2 & 13.9 & .1 & .5 \\
\hline As, Ap, Ag & 7.0 & 2.2 & 4.9 & 35.1 & 7.5 & 4.8 & 2.4 & 1.8 & 13.2 & .5 & .2 & 4.1 & 20.2 & 2.1 & 1.4 \\
\hline As, Ag, At & 5.8 & 1.2 & 3.8 & 1.9 & 9.4 & 2.4 & 9.1 & 2.1 & 3.5 & 3.5 & .2 & 3.3 & 10.6 & 1.8 & 1.0 \\
\hline $\mathrm{Ag}, \mathrm{At}$ & 4.7 & 1.8 & 4.4 & L & 9.6 & 4.3 & 5.3 & 1.4 & 6.8 & 1.9 & .1 & 2.7 & 27.8 & 8.0 & .3 \\
\hline \multicolumn{16}{|l|}{ No. 4} \\
\hline Control & 2.0 & 2.6 & 2.2 & .3 & 12.8 & .8 & 2.4 & 2.1 & 2.4 & 1.9 & $\mathrm{~L}$ & 2.5 & 7.2 & .7 & .4 \\
\hline As, Ap, At & 1.2 & 2.9 & 2.8 & .4 & 11.9 & 1.3 & 1.8 & 1.2 & 1.9 & .4 & .1 & 2.4 & 13.2 & .3 & .2 \\
\hline $\mathrm{Ap}, \mathrm{At}, \mathrm{Ag}$ & 2.4 & 2.6 & 3.4 & .1 & 5.7 & .4 & .5 & 1.7 & .1 & .5 & .4 & .1 & 4.0 & .1 & 2.1 \\
\hline As, Ap, Ag, At & 2.4 & 2.8 & 3.1 & .3 & 8.0 & 1.6 & .1 & 1.0 & 2.7 & .3 & .3 & 2.7 & 3.2 & 1.4 & 2.1 \\
\hline
\end{tabular}

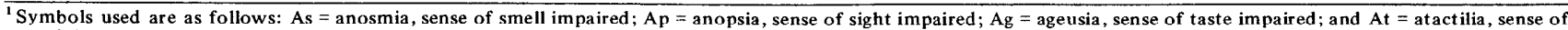
touch impaired.

${ }^{2} \mathrm{~L}=$ less than .1. 
Table 4. Statistical relationships of relative preference indices for selected treatments of sheep when compared to control sheep. Values indicate the level of significance of difference when compared to control.

\begin{tabular}{|c|c|c|c|c|c|c|c|c|c|}
\hline Plant species & $\begin{array}{l}\mathrm{Ag}^{1} \\
(1)^{2}\end{array}$ & $\begin{array}{c}\text { As, } \\
\text { (4) }\end{array}$ & $\begin{array}{l}\text { As } \\
\text { (1) }\end{array}$ & $\begin{array}{c}A p, A t, A g \\
\text { (4) }\end{array}$ & $\begin{array}{l}\mathrm{Ap} \\
(1)\end{array}$ & $\begin{array}{c}\mathrm{As}, \mathrm{Ag}, \mathrm{At} \\
\text { (3) }\end{array}$ & $\begin{array}{l}\text { At } \\
(1)\end{array}$ & $\begin{array}{c}\text { As, } \\
\text { (3) }\end{array}$ & $\begin{array}{c}\mathrm{As}, \mathrm{Ap} \\
\mathrm{Ag}, \mathrm{At} \\
\text { (4) }\end{array}$ \\
\hline \multicolumn{10}{|l|}{ Grasses } \\
\hline Alpine timothy & .02 & $\mathrm{NS}^{3}$ & NS & NS & .20 & .15 & NS & .20 & NS \\
\hline Mountain brome & .01 & .01 & NS & .01 & NS & NS & NS & NS & .02 \\
\hline Showy oniongrass & NS & NS & NS & NS & .20 & NS & NS & NS & NS \\
\hline \multicolumn{10}{|l|}{ Forbs } \\
\hline Duncecap larkspur & .05 & NS & .10 & NS & NS & $\mathrm{NA}^{4}$ & NS & NA & NS \\
\hline Leafybract aster & NS & NS & NS & .02 & NS & NS & NS & NS & NS \\
\hline Mountain knotweed & NS & NS & NS & .20 & NS & NS & .20 & NS & .05 \\
\hline Mountain sorrel & .01 & NS & NS & .20 & NS & .10 & .01 & .10 & .10 \\
\hline Northwest cinquefoil & .10 & .05 & .15 & .20 & NS & NS & NS & NS & .10 \\
\hline Pale agoseris & NS & NS & NS & .15 & NS & .10 & .10 & NS & NS \\
\hline Stickseed & NS & .05 & NS & .05 & NS & NS & NS & NS & .05 \\
\hline Sticky geranium & .01 & NS & NS & .01 & NS & .01 & NS & .01 & .01 \\
\hline Sweetanise & NS & NS & NS & NS & .20 & .02 & .20 & .05 & NS \\
\hline Thickleaf ground sel & NS & NS & NS & .15 & NS & NS & .20 & NS & .20 \\
\hline Western valarian & NS & NS & .10 & NS & NS & NS & NS & NS & NS \\
\hline Western yarrow & .02 & .15 & .01 & .20 & .01 & .15 & NS & .02 & .15 \\
\hline
\end{tabular}

cinquefoil; anosmic sheep had a preference value of 1.0 compared to 1.3 for control animals. However, the interaction of smell and taste suggested that taste was more influential in selection of this plant. When both smell and taste were controlled, the relative preference index increased, which is the same response observed with impairment of taste alone, but opposite of the response observed when smell alone was impaired (Table 3). Although this difference was not significant, it did show a tendency for the effects of taste impairment to override the effects of smell impairment. Further evidence to suggest a more important influence of taste was found when all other senses were impaired. When this occurred, preference decreased significantly; animals that could only taste took less northwest cinquefoil than control animals. When senses except smell were controlled, sheep preference remained depressed, which indicated that selection on the basis of smell was dependent upon other sensory stimuli.

Preference for grasses was primarily related to taste and sight. Preference for alpine timothy (Phleum alpinum) and for mountain brome was significantly decreased when taste was impaired. Preference for showy oniongrass (Melica spectabilis) was not significantly altered by taste treatment. Preference for showy oniongrass and alpine timothy increased when sight was impaired. This change was probably related primarily to the change in feeding behavior of the sheep when blindfolded. Anopsic sheep tended to feed longer in a specific spot and lower in the vegetation. Grasses that tended to grow lower than most other vegetation were more frequently encountered by anopsic sheep than by untreated animals. Since these lowgrowing grasses did not have other objectionable characteristics, they were consumed more frequently by anopsic sheep than by sheep that had better access to higher growing vegetation because of normal behavior. Changes in feeding behavior were only apparent for anopsic sheep.

Mountain sorrel was a forb strongly preferred because of its sour taste. When taste was impaired singly or in combination with other senses, prefercnce for sorrel decreased. Mountain sorrel a tender, succulent plant, was also preferred on the basis of touch. However, taste seemed to be more influential, as indicated by results when all senses except touch were controlled. In this case, the preference index for treated sheep was $2.4 \mathrm{com}$ pared to 69.6 for untreated sheep. Preference remained depressed when all senses except touch were impaired. When all senses except taste were controlled, no significant differences were noted between treated and control sheep.

Preference for other succulent plants, such as thickleaf groundsel, sweetanise (Osmorhiza occidentalis), and pale agoseris (Agoseris glauca), was also positively related to the sense of touch. Mountain knotweed (Polygonum montanum), not succulent but rated low in degree of coarseness, decreased in preference when touch was controlled. No plants had characteristics producing sufficiently adverse tactile stimuli to cause significant decreases in preference. The role of touch in selection was not as influential as that of other senses. Preference for thickleaf groundsel was more related to interactions of smell and taste. Sheep with smell and taste controlled showed a significantly lower preference (5.6) than untreated sheep (14.2) with $P<0.01$. Most bitter plants in this study were unpalatable; however, the bitter-tasting thickleaf groundsel was preferred when smell and taste functioned together. Since preference for groundsel decreased when only smell remained intact, it is probable that the bitter taste of this plant and its tenderness provide highly preferred stimuli for acceptance by sheep.

Sweetanise was a highly preferred plant. Acceptance of this plant decreased from RPI $=36.4$ to RPI $=$ 24.8 when taste was controlled. While the difference was not significant, it did suggest sheep preferred the sweet taste of this plant. Sweetanise, also highly succulent, was preferred on the basis of touch. Sight was also related 
to palatability of sweetanise, which is a tall-growing plant. Sheep could see sweetanise plants from any area of the pasture and would actively seek them out unless blindfolded. Other plants of exceptionally high palatability were not as obvious to sheep at long distances, and the animals did not significantly relate to sight of them.

Leafybract aster (Aster foliaceus) was both abundant and high in palatability. This aster has a faint bitter taste, but is still highly preferred by sheep on this range. Changes in preference for aster as a result of sensory impairment generally were not significant. Smell apparently was not of importance in selection of aster. Preference decreased significantly when smell was the only sense intact, indicating that other senses related to preference but smell was neutral. It was suspected from results of treatment combinations that touch was influential in determining preference for leafybract aster, but no clearcut significant relationship could be established.

Stickseed (Hackelia floribunda) was selected nearly at random by the grazing sheep. No relationship to specific senses could be established, although there were indications that sense alteration would change preference values.

\section{Discussion}

Results of this study indicated relationships of the senses to forage selection are complex. Taste appeared to be the primary sense used for selection of many species in the animals' diet, although taste frequently interacted with other senses. However, taste of some plants had no apparent influence on their palatability. Arnold (1966b) found that sheep surgically treated to control the sense of taste were unable to differentiate between species and strains of plants as successfully as intact sheep. This work was done on improved pastures in Australia, but the basic relationships of taste seem to be the same as on rangeland in this study. Longhurst and Kepner (1968) studied the effect of impairment of smell and taste in selection of feed treated with extracts from plant leaves high in volatile oils. They found taste to be of less importance in preference than smell. However, when smell and taste were both controlled, the degree of selectivity was less than if smell alone was controlled.

On the range studied, sticky geranium made up about half of dry weight production. Since selectivity of this plant was almost exclusively a function of taste, some change in the taste of this plant to improve palatability could almost double the carrying capacity. Perhaps a chemical substance could be applied to improve the taste of geranium or a fertilizer program might change palatability of this plant.

The other senses appear to supplement the sense of taste. Smell was only of specific importance in selection of northwest cinquefoil; in conjunction with taste, smell was influential in selection of certain other plant species. Tribe (1949) suggested smell was only supplementary to other senses in influencing forage selection of sheep. Arnold (1966b) found smell to be of importance and closely related to selection of plant parts or specific phenological stages of plants. Longhurst and Kepner (1968) determined that olfaction was the first sense used in making a selection and so had its greatest effect in initial forage selection.

Sight was related to selection of certain palatable plants, such as sweetanise. Other plants of high palatability, but low-growth form, could not be seen from distances greater than 10 or more feet. Consequently, no relationship to sight was shown. Arnold (1966a) found sight was not important for selection of plant species in grass-clover-alfalfa pastures, but did report changes in grazing behavior similar to those described in this paper. Arnold did not blindfold the sheep; he restricted their vision with "blinkers" that did not totally obstruct sight except at the point of forage selection.

Plants selected, at least in part, on the basis of touch were all categorized as "low" in coarseness; generally they were succulent. Overall, touch appeared primarily to supplement the sense of taste in selection of plant species.

When all four senses were impaired, sheep showed some interesting alterations in forage preference. Changes in preference did not result in completely random forage selection; however, plants of low palatability, such as geranium and western yarrow, increased in preference after impairment of all four senses. Plants of high palatability, such as mountain sorrel and thickleaf groundsel, decreased in preference. Although sensory impairment was severe, some factors influencing forage selection, such as touch in the tongue and the common chemical sense, were not controlled. Arnold (1966b) reported the control of smell, taste, and touch in combination did not completely alter animal forage preference in an area where sight was of minor importance. Longhurst and Kepner (1968) in feeding trials of sheep also found impairment of smell, taste, and touch in combination did not completely alter sheep forage preferences.

\section{Literature Cited}

Arnold, G. W. 1966a. The special senses in grazing animals. I. Sight and dietary habits in sheep. Aust. J. Agr. Res. 17:521-529.

Arnold, G. W. 1966h. The special senses in grazing animals. II. Smell, taste, and touch and dietary habits in sheep. Aust. J. Agr. Res. 17:531-542.

Buchanan, H., W. A. Laycock, and D. A. Price. 1972. Botanical and nutritive content of the summer diet of sheep on a tall forb range in southwestern Montana. J. Anim. Sci. 35:423-430.

Caldwell, M. M., and R. T. Moore. 1971. A portable smallstage photoelectric planimeter for leaf area measurements. J. Range Manage. 24:394-395.

Draper, N. R., and H. Smith. 1966. Applied regression analysis. John Wiley and Sons, Inc., New York. 407 p.

Heady, H. F., and D. T. Torell. 1959. Forage preferences exhibited by sheep with esophageal fistulas. J. Range Manage. 12:28-33.

Krueger, W. C. 1972. Evaluating animal forage preference. J. Range Manage. $25: 471-475$.

Longhurst, W. M., and R. E. Kepner. 1968. Strontium-90 and Cesium-137 food chain relationships to deer and sheep. V. Factors influencing radionuclide accumulation. Progress Report. AEC Project No. UCD 34, p. 104-112. (68 p. mimeo.)

Marten, G. C. 1970. Measurement and significance of palatability. In: Proc. of National Conference on Forage Quality Evaluation and Utilization. D1-D55. Nebraska Center for Continuing Education, Lincoln.

Osol, A., and G. E. Farrar, Jr. 1955. The dispensatory of the United States of America. J. B. Lippincott Co., Philadelphia, Pa. 2139 p.

Ostle, B. 1963. Statistics in research, 2 nd ed. Iowa State Univ. Press, Ames. 585 p.

Tribe, D. E. 1949. The importance of the sense of smell to the grazing sheep. J Agr. Sci. 39:309-312.

Ward, A. L. 1970. Stomach content and fecal analysis: Methods of forage identification. In: Range and wildlife habitat evaluation-a research symposium, $p$. 146-158. U.S. Dep. Agr. Misc. Publ. 1147.220 p. 